\title{
The Role of Capital Structure on The Effect of Dividend Policy and Business Risk on Firm Value (Evidence from Indonesian Manufacturing Company)
}

\author{
ANGGIT ESTI IRAWATI* \\ ERNA FITRI KOMARIYAH \\ University of Technology Yogyakarta
}

\begin{abstract}
This study examines the effect of dividend policy and business risk on firm value and capital structure. Moreover, this study analyzes the role of capital structure in that relationship simultaneously. The relationship between these variables has been a debate in the capital market literature. Using manufacturing companies listed on Indonesia Stock Exchange (IDX) for years 2012-2018, this study takes into account that the dividend policy and business risk do not directly impact the firm value. Thus, we examine 41 companies that meet the sample criteria. The result shows that dividend policy and business risk have a positive effect both on firm value and capital structure. Then, capital structure has a role in mediating the effect of dividend policy, and business risk on firm value has been confirmed.
\end{abstract}

Keywords: Capital Structure, Dividend Policy, Business Risk, Firm Value.

Abstrak: Penelitian ini menguji pengaruh kebijakan dividen dan risiko bisnis pada nilai perusahaan. Selain itu, penelitian ini menganalisa peran struktur modal pada hubungan itu secara bersamaan. Hubungan antara variabel-variabel tersebut telah menjadi perdebatan dalam literatur pasar modal. Dengan menggunakan perusahaan manufaktur yang terdaftar di Bursa Efek Indonesia (BEI) selama tahun 2012-2018, studi ini memperhitungkan bahwa kebijakan dividen dan risiko bisnis tidak berdampak langsung terhadap nilai perusahaan. Dengan demikian, kami memeriksa 41 perusahaan yang memenuhi kriteria sampel. Hasilnya menunjukkan bahwa kebijakan dividen dan risiko bisnis memiliki pengaruh positif baik pada struktur modal maupun pada nilai perusahaan. Kemudian, struktur modal memiliki peran untuk memediasi pengaruh kebijakan dividen dan risiko bisnis pada nilai perusahaan telah terkonfirmasi.

Kata kunci: Struktur Modal, Kebijakan Dividen, Risiko Bisnis, Nilai Perusahaan. 


\section{Introduction}

This study examines the influence of policy and business risk on firm value and capital structure. Literature shows mixed results about that relationship (Barros et al., 2019). Some studies prove the positive, negative, and insignificant influences. Therefore, this study investigates whether the relationship is likely to be mediated by another variable. Thus, this study takes into account whether the capital structure can imposition the relationship.

Capital structure is the balance between the amount of debt with its capital owned by the company (Brigham \& Ehrhardt, 2010). Therefore, there needs to be a policy to balance both wishes through the dividend policy. A company has the optimal capital structure if they have a combination of debt and equity (external source) that maximizes the stock price of the company. The financial manager is required to create an optimal capital structure by collecting funds from inside and outside the company efficiently, which means that the funding decision can minimize the cost of capital or maximize firm performance. Decisions taken by the company's financial managers will affect the firm value represented by the stock price.

On the other hand, business risk factors can affect capital structure through debt. The business risk will increase when the company has high debts to meet the needs of its funding because the cost burden incurred by the company has also increased. The business risk may also increase due to competition in the increasingly stringent business world. Therefore, to mitigate such risks should be supported with excellent performance for the company's goal to maximize profit achieved.

According to signaling theory, the decision making of the dividend policy can provide signals or information to external parties. The increasing dividend payment by the company to investors is considered good news. The firm value will increase when the company decides to distribute dividends. It aims to maximize shareholder value, and the resulting cash flow is the property of shareholders (E. F. Brigham \& Ehrhardt, 2010).

Two theories have different thoughts on the capital structure, namely pecking order theory and trade-off theory. Pecking order theory (Myers, 1984) raises the selection of 
the company's funding source by order. The first order is internal financing (retained earnings). In the event of a financial deficit, the company chooses an external loan in

the form of debt compared to issuing a new stock because the long-term debt emission costs are lower than with new stock emission costs. Also, the manager's concern that new stock issuance could be interpreted as bad news for a financier, resulting in declining the firm value.

On the other hand, the trade-off theory explains the relationship between taxes, bankruptcy risk, and the use of debt caused by the decision of the capital structure taken by the company (Brealey et al., 2008). The purpose of the trade-off theory is to balance the benefits and sacrifices incurred as a result of debt use (Myers, 1984). Thus, decisions about determining capital structure are essential to the company.

Then, this paper is organized as follows. Section 2 explains the theoretical framework and how hypotheses are developed. Section 3 presents the data and the research method. The statistical results and analysis are provided in section 4. Finally, section 5 presents conclusions, limitations, and future research.

\section{Theoretical Framework and Hypothesis Development}

\subsection{Signaling Theory}

Signaling Theory is a management step to provide implicit instructions to investors on how investors perceive the prospects of the company (Bhattacharya, 1979; John \& Williams, 1985; Miller \& Rock, 1985). This theory refers to the thought that the manager gives investors a signal of how they see the company's prospects (Brigham \& Houston, 2010; Mustofia et al., 2019). It aims to raise the firm value. The signals given are information about what the management has done to realize the wishes of the owner.

Dividend announcements always get a response in the capital market, both positive and negative (Dasilas \& Leventis, 2011). Based on the signaling hypothesis by Bhattacharya (1979), the dividend increase is usually often followed by rising stock prices. The literature has also proved to be such research as Woolridge (1982), Bajaj \& Vijh (1990), Dyl \& Weigand (1998), Nissim \& Ziv (2001), and Lie (2005). Conversely, 
the decline in dividends in general causes the stock price to drop (Impson, 1997). As such, the cash dividend serves as a signal of cash flow in a profitable.

\subsection{Pecking Order Theory}

Myers \& Majluf (1984) Formulate a theory of capital structure called pecking order theory. This theory bases the information of asymmetry (asymmetric information) that management has more information about the prospects of the company than investors (Brealey, Myers, \& Allen, 2008; Myers \& Majluf, 1984). This asymmetric information affects the choice between internal funds source or external funds (debt) as well as additional capital participation from the internal funds or publishing new equity.

Pecking order theory states the order of funding that can be chosen management (Brealey, Myers, \& Allen, 2008; Jahanzeb et al., 2013). First, the company prefers internal funding. Second, the company will endeavor to adjust the dividend distribution ratio with the investment opportunity encountered. It is an attempt not to make a substantial change in dividend payments. Third, dividends payments that tend to be constant in volatile conditions result in internal funds sometimes overused or lacking to invest. If the funding for the operation is less than the investment requirement, the company will reduce the cash balance or sell the securities owned. Fourth, if external funding is required, the company will issue the safest securities first. The issuance of securities will be initiated from the issuance of bonds, then bonds that can be converted into its capital just finally issued new stock.

The company prefers external financing in the form of debt versus issuing new shares (Brealey, Myers, \& Allen, 2008; Jahanzeb et al., 2013). It happens because longterm debt emission costs are cheaper compared to new stock emission costs (Baskin, 1989; Shyam-Sunder \& Myers, 1999). Also, Holmes \& Kent (1991) and Hamilton \& Fox (1998) found that managers were worried that the new stock is suance made him lose control of the company. Thus, the issuance of new shares was an option of the last choice in the decision taken (Bistrova et al., 2011; Huang \& Ritter, 2009). 


\subsection{Trade-off theory}

The trade-off theory explains the relationship between taxes, bankruptcy risk, and the use of debt caused by the decision of the capital structure taken by the company (Brealey, Myers, \& Marcus, 2008; Kraus \& Litzenberger, 1973). This theory intends to balance the benefits and sacrifices incurred as a result of debt use (Frank \& Goyal, 2003; Myers, 1984). The trade-off model assumes that the company's capital structure is the result of a trade-off of the tax profit using the debt and costs that will arise as a result of the use of the debt (Brigham \& Houston, 2010). The company can increase debts during more significant benefits. However, if the sacrifice due to debt use has already been greater, additional debt is not allowed. Sacrifice for using the debt can be in the form of bankruptcy cost and agency cost.

\subsection{Firm Value}

Firm value is an investor's perception of the company based on the stock market price. The stock price was formed upon the strong demand and supply that occurred in the capital market (Sia \& Tjun, 2011). Hing stock market prices depict high company values (Ernawati \& Widyawati, 2015; Prasetia et al., 2014). The high firm value illustrates the excellent performance of the company (Brigham \& Gapenski, 1996). Thus, the high firm value can be measured using the stock market price. It will make the market believe that the firm is not only able to perform at this time but also have prospects in the future (Prasetia et al., 2014). Therefore, the company seeks to increase the stock market price to show good performance results and improve the welfare of the owner.

\subsection{The Effect of Dividend Policy on Firm Value}

Decision making about the dividend policy often affects the share price (Barros et al., 2019). Kraft et al. (2013) and Anderson \& Reeb (2003) indicate that companies that pay dividends have an abnormal return than the company that does not. It relates to signaling theory that the dividend payment by the company to investors is regarded as 
good news. Furthermore, the positive signals increase the stock price and ultimately increase the firm value.

Studies that test the influence of the dividend policy against the firm value still have not demonstrated consistent results. Barros et al. (2019) said that the discussion about this policy dividend is controversial. Some argue that a policy dividend is relevant to firm value, but on the other hand, the agency theory claims that both things are relevant. Then, Kraft et al. (2013) indicate that the dividend policy has a positive and significant effect on the firm value. However, the research channeled by Mardiastanto $\&$ Raharjo (2014) indicates that the dividend policy does not affect the firm value. Thus, the proposed hypothesis was:

$\mathbf{H}_{1}$. The dividend policy has a positive effect on firm value.

\subsection{The Effect of Business Risk on Firm Value}

Business risk is the predictability of the projection of returns on future assets (Brigham \& Houston, 2010). These risks can be described by the probability of failure of the company in operation or environment. Such failures may interfere with the Organization's ability to make a return on investment, even under certain circumstances that may affect the company's capabilities. The value of companies that have high business risk will also drop in the eyes of investors when bankruptcy occurs. Consequently, the assets owned by the company will be sold to settle a large amount of debt compared to return the value of the invested share of the investor.

The literature on the influence of business risk to the firm value shows mixed results. The research of Wiagustini \& Pertamawati (2015) shows that business risk is negatively and significantly influential. However, Reswari et al. (2016) found that the business risk of influence is not significant to the firm value. This research uses the EBIT ratio to measure business risk. This ratio is one of the ratios for predicting the bankruptcy level of a company proposed by Altman (1968). The EBIT ratio demonstrates the company's ability to generate profits. When the company can generate profit, the company value will be good. Thus, the proposed hypothesis was: 
$\mathbf{H}_{2}$. Business risk has a positive effect on firm value.

\subsection{The Effect of Dividend Policy on Capital Structure}

The dividend policy is a decision whether profits earned will be distributed to shareholders as dividends or will be withheld as retained earnings (Deitiana, 2011). Policy on dividend payments is a crucial decision in a company. This policy involves two parties that have different interests, namely the first Party of shareholders, and the second party is the company itself.

On the other hand, Brigham \& Houston (2010) argued that any dividend payments made by the company to shareholders could affect the high low of the company's external equity. Following pecking order theory (Myers \& Majluf, 1984) states that the company is prioritizing internal funds to meet its needs. If the company's internal funds are not adequate for the necessary needs, the company will use an alternative to find external funds in the form of debts. The higher the proportion of debt used for a company's capital structure, the higher the number of obligations. The increase in debt affects the sizeable net profit available to investors, including dividends that will be accepted, as these obligations are prioritized more than dividend distribution (Kraft et al., 2013). Thus, the proposed hypothesis was:

H3. The dividend policy has a positive effect on capital structure.

\subsection{The Effect of Business Risk on Capital Structure}

Business risk is uncertainty over the projection of returns on future assets (Brigham $\&$ Houston, 2010). The uncertainty is an assumption of future revenue projections if the company does not use debts (Yeniatie \& Destriana, 2010). Companies can have a high business risk when the company uses high debts (Ria \& Lestari, 2015). It means that the business risk increases with the increase in costs of the company's loans.

The literature shows that business risk is one of the determinants of the corporate capital structure (Brealy \& Myers, 1988; Castanias, 1983; Chakraborty, 2015; Kale et al., 1991). However, previous research, still showing mixed results. On one side of the literature shows that business risk is negatively affecting the capital structure (Bradley 
et al., 1984; Flath \& Knoeber, 1980; Friend \& Lang, 1988). Some studies have found ambiguous results (Scott Jr, 1976; Wald, 1999). Some studies have also found no significant association (Reswari et al., 2016; Titman \& Wessels, 1988). On the other hand, the literature shows a positive relationship between the two (Chu et al., 1992; Kim \& Sorensen, 1986; Myers, 1977; Wiagustini \& Pertamawati, 2015). This study held the final opinion predicting that the business risk has a positive effect on the capital structure. It is because significant business risks can reduce the agency cost of debt. Thus, the proposed hypothesis was:

\section{H4. Business risk has a positive effect on capital structure.}

\subsection{The Effect of Capital Structure on Firm Value}

The capital structure is the proportion of funding between debt and equity (Weston \& Copeland, 2010). The capital structure is one of the financial decisions faced by the company's financial managers. In this case, the financial manager should decide by comparing the debt and equity used for operations (Cuong \& Canh, 2012). It is found that the combination of a long-term source of funds consisting of two primary sources, which are derived from internal and external companies (Rodoni \& Ali, 2010). The decision to choose the funding source or the composition of the selection of the funding is called the capital structure.

An optimal capital structure occurs when a balance between risk and return achieved. The optimal capital structure can be interpreted as a capital structure that has a proportion of debt to the equity that is higher than that of its industry average (Van Horne et al., 2013). It means that companies can minimize the cost of overall capital use or average capital costs to maximize the firm value. Therefore, it is necessary to have an optimal balance between the debt and its capital.

The first research to theoretically test the influence of the capital structure to the firm value is Modigliani \& Miller (1958). Unfortunately, the literature shows mixed results in the relationship (Booth et al., 2001; Fama \& French, 1998; Graham, 2000). Nieh et al. (2008) pointed out that the debt ratio affects firm value positively. It means that the optimal debt ratio can improve firm value. However, the research conducted by 
Elkelish (2007) showed that the debt to equity ratio has no impact on firm value. Thus, the proposed hypothesis was:

H5. Capital structure has a positive effect on firm value.

\subsection{The Effect of Dividend Policy and Business Risk on the Firm Value Mediated} by the Capital Structure.

Management needs to make the right decision to produce an optimal dividend policy. It means that management can create a balance between current dividends and future growth to maximize the firm value. The larger the company's debt, the dividend being distributed decreases, it affects the lower the value achieved by the company (Kristianti, 2013). Based on the signaling theory (Bhattacharya, 1979), a decision on the dividend policy can provide signals or information on the external authorities regarding the condition of the company. Thus, the investor sees the company able to manage the operation well, so it has an optimal capital structure. The positive views will indirectly increase the firm value, as investors will tend to choose it for investment.

This research intends to investigate whether the capital structure is the relationship between dividend policy and business risk to the firm value. Thus, the proposed hypothesis was:

H6. The capital structure mediates the influence of dividend policy on firm value.

H7. The capital structure mediates the influence of business risk on firm value.

Figure 1.

Research Model

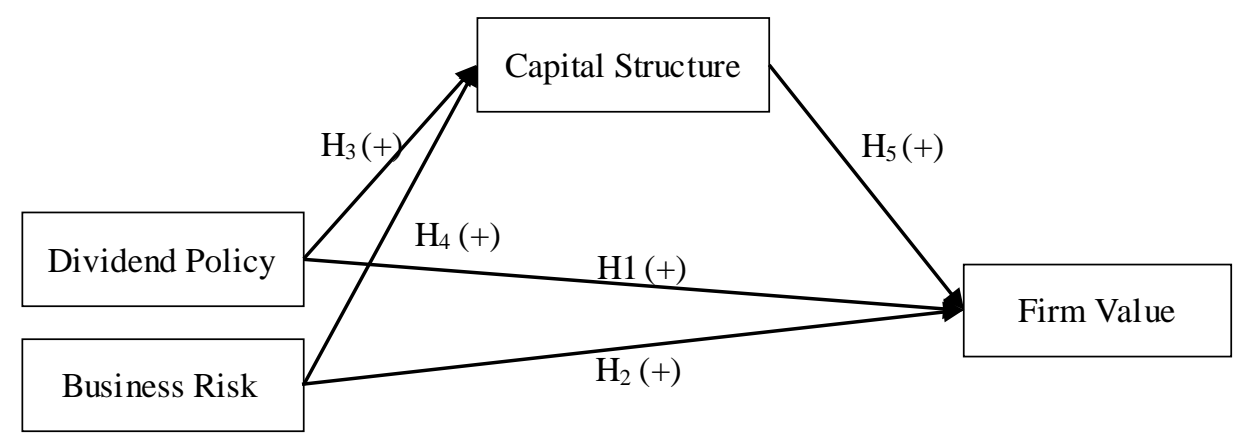




\section{Research Method}

\subsection{Data Selection and Collection Approach}

This study uses data derived from the annual report of manufacturing companies from the 2012-2018 period. The selected company is a manufacturing company listed on Indonesia Stock Exchange (IDX) and publishes its annual report consistently from 2012 through 2018. The companies listed on the exchange during the research period are as many as 168 companies, but 33 of them do not publish annual reports consistently. Also, this research limits samples to companies that use rupiah currency and gains and distributes dividends during the research period. More specifically, the company must have information about the dividend policy, business risk, capital structure, and company value. This study issued 94 companies from samples for not meeting these criteria. Thus, the final samples used in this study were as many as 41 companies in times with seven years of observation. In detail, table 1 presents the data.

Table 1.

Sample Characteristics.

\begin{tabular}{lc}
\hline \multicolumn{1}{c}{ Criteria } & $\mathrm{n}$ \\
\hline An IDX-listed manufacturing company in 2012-2018 & 168 \\
\hline $\begin{array}{l}\text { Companies that do not publish financial statements and annual reports } \\
\text { consistently during the year 2012-2018 }\end{array}$ & $(33)$ \\
\hline $\begin{array}{l}\text { Companies that do not have the completeness of data on dividend policy, } \\
\text { company growth, business risk, capital structure, and firm value. }\end{array}$ & $(3)$ \\
\hline Financial statements do not use IDR currency & $(9)$ \\
\hline Manufacturing companies not distributing dividends during the year 2012-2016 & $(73)$ \\
\hline Manufacturing companies that do not earn a profit during the year 2012-2016 & $(9)$ \\
\hline Year of observation & $\mathbf{7}$ \\
\hline Total samples & $\mathbf{2 8 7}$ \\
\hline
\end{tabular}

\subsection{Measurement}

The dividend policy in this study was proscribed with the dividend payout ratio (DPR). This ratio is used to measure the amount of net profit distributed as dividends to each holder of one common stock sheet (Gibson, 2001). The dividend payout ratio is calculated using the formula: 


$$
\text { DPR }=\frac{\text { Dividend Per Share }}{\text { Earnings Per Share }}
$$

The measurement of business risk in this study refers to Erdiana \& Mawardi (2011), which is measured by the standard deviation of the Earnings Before Interest and Tax (EBIT) ratio compared to the total assets. According to the rule of thumb, the standard deviation is high if the value is more than one. Business risk is calculated using the formula:

$$
\text { Business risk }=\frac{\sigma \text { EBIT }}{\text { Total Asset }}
$$

The capital structure in this study is a comparison of all debts with its capital Debt to Equity Ratio (DER). This measurement refers to the research of Chowdhury \& Chowdhury (2010) and Muhammad et al. (2014). DER is calculated using the formula:

$$
\text { DER }=\frac{\text { Total Liability }}{\text { Total Equity }}
$$

One of the alternatives used to measure the firm value is Tobin's $Q$. This research measures the firm value using Tobin's $Q$, which refers to the research of Chung \& Pruitt (1994) and Salim \& Yadav (2012). This ratio provides the best information in terms of all elements of debt and stock capital of the company. Tobin's Q is calculated through the number of Market Value of Common Stock, Preferred Stock, and Book Value of Debt compared to the company's total assets. The firm value is measured using the formula:

$$
\text { Tobin's } Q=\frac{\text { MVCS }+ \text { PS }+\mathrm{D}}{\mathrm{TA}}
$$

\subsection{Data Analysis}

This study uses the Partial Least Square (PLS) following a variant-based Structural equation Modeling (SEM) equation model that can simultaneously perform structural testing. PLS is a soft analysis method because it eliminates the assumptions of Ordinary Least Squares (OLS), such as having to distribute the normal multivariate and the absence of the problem of multicollinearity between variables exogenous (Kotz et al., 1982). 
This study uses two stages of analysis of the structure model on PLS. First, the inner model analysis examines to ensure that the structural model is constructed robust and accurate. Evaluation of Inner models can be seen from several indicators, namely coefficient of determination (R2), predictive relevance (Q2), and Goodness of Fit Index $(\mathrm{GoF})$. The study evaluates structural construct models with Average R-Square (ARS), Average Path Coefficient (APC), and Average Variance Inflation Factor (AVIF). ARS used to assess the magnitude of the influence of exogenous, endogenous, and mediation variables can be said to be good if the value of the ARS is $<0.05$. APC is used to view the relationship between variables that can be said well if the APC value is $<0.05$. AVIF is used to view the magnitude of the correlation between endogenous/multicollinearity variables that can be said well if the AVIF value is <5. Secondly, the hypothesis testing was analyzed at $5 \%$ significance level.

\section{Results and Discussion}

\subsection{Descriptive Statistical Analysis}

Table 2 describes the descriptive statistics analysis results. The information presented mean, standard deviation, and range. The mean represents a value of 2.259, a standard deviation of 3.858, as well as a range of difference between the high and maximum values. The dividend policy measured using the Dividend Payout Ratio (DPR) shows an average value of 0.003 , a standard deviation of 0.004 , and a less high range. The average business risk variable indicates a value of 0.053 , a standard deviation of 0.043 , and a high range. The capital structure measured using the Debt Equity Ratio (DER) shows an average value of 0.813 , a standard deviation of 0.773 , and a high range.

Table 2.

Descriptive statistics.

\begin{tabular}{lccc}
\hline \multicolumn{1}{c}{ Variable } & Mean & Standard deviation & Range \\
\hline Nilai Perusahaan & 2,259 & 3,858 & $-1,089-29,250$ \\
Dividend policy & 0,003 & 0,004 & $0,000-0,041$ \\
Risiko Bisnis & 0,053 & 0,043 & $0,006-0,411$ \\
Struktur Modal & 0,813 & 0,773 & $0,079-5,152$ \\
\hline
\end{tabular}




\subsection{Inner Model Analysis}

Table 3.

Inner Model Test Results

\begin{tabular}{lc}
\hline \multicolumn{1}{c}{ Variable } & R-Square \\
\hline Dividend policy (DPR) & - \\
Business risk (BSR) & - \\
Capital structure (DER) & 0,14 \\
Firm value (FRV) & 0,40 \\
\hline
\end{tabular}

This study analyzes the inner model using the Q-Square predictive Relevance (Q2) value size which is calculated based on the R-Square value of each variable. The value of Q2 is:

$$
\begin{aligned}
\mathrm{Q}^{2} & =1-\left(1-\mathrm{R}^{2} \mathrm{DER}\right)\left(1-\mathrm{R}^{2} \mathrm{FRV}\right) \\
& =1-(1-0,14)(1-0,40) \\
& =1-(0,86)(0,6) \\
& =1-0,516 \\
& =48,4 \%
\end{aligned}
$$

Based on the calculations, the value of Q2 is $48.4 \%$, indicating that the dividend policy and business risk variables in this study were able to explain the firm value variables at $48.4 \%$. At the same time, the remainder amounted to $51.6 \%$ Described by other variables.

To test the goodness of fit models, the APC, ARS, and AVIF indicators are used. Table 3 shows the result of the fit indicator, i.e., Average Path Coefficient (APC), Average R-squared (ARS), and Average Variance Inflation Factor (AVIF). All the goodness of fit criteria in the test are met evidenced by the P values for APC, and ARS, respectively, are $<0.001$, which means significant. Meanwhile, the value of AVIF is also fulfilled because its value is less than 5 .

Table 3.

Goodness of Fit

\begin{tabular}{ll}
\hline Criteria & Cut-off standards \\
\hline APC $=0,274$ & $\mathrm{P}<0,001$ \\
ARS $=0,270$ & $\mathrm{P}<0,001$ \\
AVIF $=1,097$ & $<5$ \\
\hline
\end{tabular}




\subsection{Hypothesis Testing}

This study tested the hypothesis using WarpPLS. Hypotheses are supported when the P-value is less than 5\%. The relationship between dependent variables and independent variables in this study can be seen from the value of the path coefficient $(\beta)$. A positive sign in $\beta$ indicates a positive relationship between independent variables and independent variables. According to table 4, all hypotheses are supported. H1 states that the dividend policy has a positive effect on the firm value; this hypothesis is supported by $\beta$ values of 0.28 and $P<0.01$. It results in line with Kraft et al. (2013) that the dividend policy has a significant positive effect on the firm value.

$\mathrm{H} 2$ states that business risk has a positive effect on the firm value; this hypothesis is supported by a positively marked $\beta$ value of 0.41 and $\mathrm{P}<0.01$. Thus, business risk has a significant positive influence on firm value. It means that the company, with the ability to generate profits, can increase firm value. Furthermore, H3 and H4 state that the dividend policy and the business risk positively affect the capital structure are also supported. It means that the capital structure is determined by the dividend policy and the business risk. Thus, it implies that the managers should make the decision that considers optimal cost and benefit.

Last, H5 states that the capital structure has a positive effect on the firm value supported by a positively marked $\beta$ value of 0.20 and $\mathrm{P}<0.01$. Therefore, the capital structure has a significant positive effect on firm value. It means that the optimal debt ratio can improve the firm value, as Nieh et al. (2008) suggested. Then, statistic results are presented in Table 4. and Figure 2.

Figure 2 .

Result of hypothesis testing

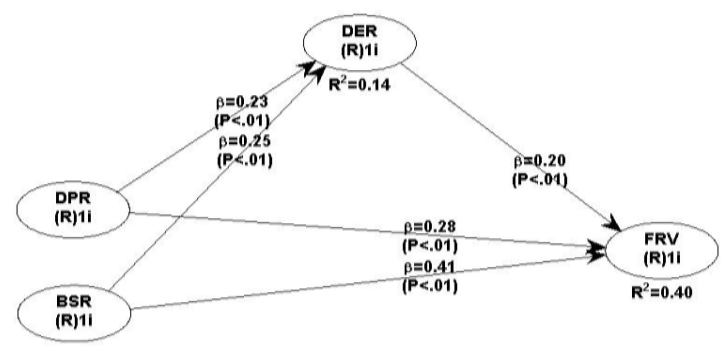


Table 4.

Hypothesis Testing Results Summary

\begin{tabular}{ccccc}
\hline Hypothesis & Coefficient $(\beta)$ & P-Value & Result & Relationship \\
\hline H1 & 0,28 & $<0,01$ & Supported & $(+)$ \\
H2 & 0,41 & $<0,01$ & Supported & $(+)$ \\
H3 & 0,23 & $<0,01$ & Supported & $(+)$ \\
H4 & 0,25 & $<0,01$ & Supported & $(+)$ \\
H5 & 0,20 & $<0,01$ & Supported & $(+)$ \\
\hline
\end{tabular}

\subsection{Mediation Analysis}

This study tested three equations model to analyze the role of mediation, as suggested by Baron \& Kenny (1986). Equation 1 examines independent variables (dividend policy and business risk) against dependent variables (corporate values). Equation 2 examines independent variables (dividend policy and business risk) against variable mediation (capital structure). Equation 3 tests independent variables (dividend policy and business risk) against dependent variables (corporate values) through mediation variables (capital structure).

According to Baron \& Kenny (1986), mediation testing can be done if equation one and equation 2 indicate significant influence. If both criteria are met, Equation 3 can be run. Dependent variables are examined on independent variables and mediation variables. If it is not supported, the test must be stopped. A variable has a full mediation effect if independent variables (dividend policy and business risk) have no influence on the dependent variable (company value) when inserted mediation, or in this case, is equation 3. Then, a variable has partial mediation influence when the value of $\beta$ in equation 3 differs from the $\beta$ value in equation 1 .

Table 5 shows the test results for each equation. In equation 1 , the dividend policy and business risk to the firm value have a significant effect with each value of $\beta=0.26$ and $\beta=0.48, \mathrm{P}<0.01$. In Equation 2, the dividend policy and business risk have a significant effect on the capital structure with each value of $\beta=0.23$ and $\beta=0.25, P<$ 0.01. Besides, the relationship between dividend policy and business risk to the firm value remains significant when the capital structure is added as a mediation variable. It 
indicates that the capital structure is partially mediate. Thus, this test supports H6 and H7.

Table 5 .

Mediation Impact Testing Results

\begin{tabular}{lcc}
\hline \multicolumn{1}{c}{ Variable } & Coefficient $(\beta)$ & P-Value \\
\hline $\begin{array}{l}\text { Equation 1: } \\
\text { Dividend policy } \\
\text { Business risk }\end{array}$ & 0,26 & $<0,01$ \\
\hline $\begin{array}{l}\text { Equation 2: } \\
\text { Dividend policy }\end{array}$ & 0,48 & $<0,01$ \\
Business risk & 0,23 & $<0,01$ \\
\hline Equation 3: & 0,25 & $<0,01$ \\
$\begin{array}{l}\text { Dividend policy } \\
\text { Business risk } \\
\text { Capital structure }\end{array}$ & 0,28 & $<0,01$ \\
\hline Significant at 5\% & 0,41 & $<0,01$ \\
Equation 1: $\mathrm{R}^{2}=0,37$, Variabel Dependen: Firm Value & \\
Equation 2: $\mathrm{R}^{2}=0,14$, Variabel Dependen: Capital structure & \\
Equation 3: $\mathrm{R} 2=0,40$, Variabel Dependen: Value & \\
\hline
\end{tabular}

Figure 2.

Equation 1

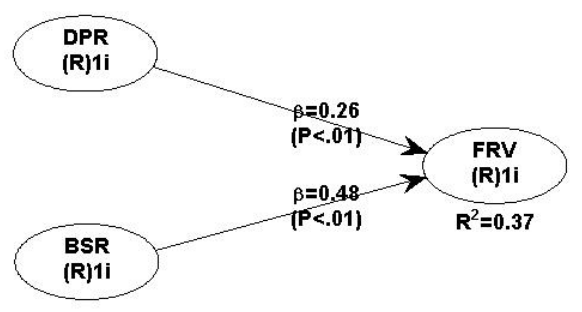

Figure 3.

Equation 2

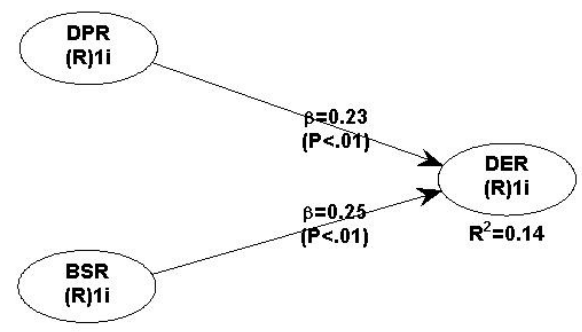




\section{Conclusion, Implication, and Limitation}

This research provides empirical evidence of the relationship between dividend policy, business risk, capital structure, and corporate value. Dividend policy and business risk affect the capital structure positively, and capital structure also affects the firm value. This study also found evidence that the capital structure can mediate the effect of dividend policy and business risk on the firm value partially. Thus, the study contributed evidence for the debate of existing relationships.

Furthermore, this study contributed to the literature that has mixed results by proposing a capital structure as mediation. However, this study conducts relationship testing between variables linearly. Although this research can prove the role of mediation from the capital structure, a vast difference of results indicates the possibility of a relationship that is not linear. Further research can prove it empirically. On the other hand, this study used only the EBIT ratio as a proxy of business risk. Subsequent studies may be able to consider another proxy from Altman (1968) or develop more precise measurements, so this research becomes rich.

\section{Reference}

Altman, E. I. (1968). Financial ratios, discriminant analysis, and the prediction of corporate bankruptcy. The Journal of Finance, 23(4), 589-609.

Anderson, R. C., \& Reeb, D. M. (2003). Founding-family ow nership, corporate diversification, and firm leverage. The Journal of Law and Economics, 46(2), 653-684.

Bajaj, M., \& Vijh, A. M. (1990). Dividend clienteles and the information content of dividend changes. Journal of Financial Economics, 26(2), 193-219.

Baron, R. M., \& Kenny, D. A. (1986). The moderator-mediator variable distinction in social psychological research: Conceptual, strategic, and statistical considerations. Journal of Personality and Social Psychology, 51(6), 1173.

Barros, V., Matos, P. V., \& Sarmento, J. M. (2019). What firm's characteristics drive the dividend policy? A mixed-method study on the Euronext stock exchange. Journal of Business Research. 
Baskin, J. (1989). An empirical investigation of the pecking order hypothesis. Financial Management, 26-35.

Bhattacharya, S. (1979). Imperfect information, dividend policy, and "the bird in the hand" fallacy. Bell Journal of Economics, 10(1), 259-270.

Bistrova, J., Lace, N., \& Peleckiené, V. (2011). The influence of capital structure on Baltic corporate performance. Journal of Business Economics and Management, 12(4), 655669.

Booth, L., Aivazian, V., Demirguc-Kunt, A., \& Maksimovic, V. (2001). Capital structures in developing countries. The Journal of Finance, 56(1), 87-130.

Bradley, M., Jarrell, G. A., \& Kim, E. H. (1984). On the existence of an optimal capital structure: Theory and evidence. The Journal of Finance, 39(3), 857-878.

Brealey, R. A., Myers, S. C., \& Allen, F. (2008). Brealey, Myers, and Allen on valuation, capital structure, and agency issues. Journal of Applied Corporate Finance, 20(4), 49-57.

Brealey, R. A., Myers, S. C., \& Marcus, A. J. (2008). Dasar-dasar manajemen keuangan perusahaan. Jakarta: Erlangga.

Brealy, R. A., \& Myers, S. C. (1988). Fundamentals of corporate finance. New York: McGraw Hill.

Brigham, E. F., \& Ehrhardt, M. C. (2010). Financial management: theory and practice. -1119 ps.

Brigham, Eugene F., \& Gapenski, L. C. (1996). Intermediate finance management. J. Harbour Drive, The Dryden Press.

Brigham, Eugene F., \& Houston, J. F. (2010). Essentials of financial management. Engage Learning Asia.

Castanias, R. (1983). Bankruptcy risk and optimal capital structure. The Journal of Finance, $38(5), 1617-1635$.

Chakraborty, I. (2015). The effect of business risk on the capital structure of Indian Corporate Firms: Business groups vs. stand-alone firms. Global Economic Review, 44(2), 237268.

Chowdhury, A., \& Chowdhury, S. P. (2010). Impact of capital structure on firm's value: Evidence from Bangladesh. Business and Economic Horizons (BEH), 3(1232-2016101116), 111-122.

Chu, P. Y., Wu, S., \& Chiou, S. F. (1992). The determi nants of corporate capital structure choice: Taiwan evidence. Journal of Management Science, 9(2), 159-177. 
Chung, K. H., \& Pruitt, S. W. (1994). A simple approximation of Tobin's q. Financial Management, 70-74.

Cuong, N. T., \& Canh, N. T. (2012). The effect of capital structure on firm value for Vietnam's seafood processing enterprises. International Research Journal of Finance and Economics, 89(89), 221-233.

Dasilas, A., \& Leventis, S. (2011). Stock market reaction to dividend announcements: Evidence from the Greek stock market. International Review of Economics \& Finance, 20(2), 302-311.

Deitiana, T. (2011). Pengaruh rasio keuangan, pertumbuhan penjualan dan dividen terhadap harga saham. Jurnal Bisnis Dan Akuntansi, 13(1), 57-66.

Dyl, E. A., \& Weigand, R. A. (1998). The information content of dividend initiations: Additional evidence. Financial Management, 27(3), 27.

Elkelish, W. W. E. (2007). Impact of culture on stock market development and corporate governance.

Erdiana, H. E., \& Mawardi, W. (2011). Analisis Pengaruh Firm Size, Business Risk, Profitability, Assets Growth, dan Sales Growth terhadap Struktur Modal (Studi Kasus Pada Perusahaan Real Estate and Property yang terdaftar di BEI Periode 2005-2008). Universitas Diponegoro.

Ernawati, D., \& Widyawati, D. (2015). Effect of Profitability, Leverage, and Company Size on Firm Value. Journal of Accounting Science \& Research, 4(1).

Fama, E. F., \& French, K. R. (1998). Taxes, financing decisions, and firm value. The Journal of Finance, 53(3), 819-843.

Flath, D., \& Knoeber, C. R. (1980). Taxes, failure costs, and optimal industry capital structure: An empirical test. The Journal of Finance, 35(1), 99-117.

Frank, M. Z., \& Goyal, V. K. (2003). Testing the pecking order theory of capital structure. Journal of Financial Economics, 67(2), 217-248.

Friend, I., \& Lang, L. H. (1988). An empirical test of the impact of managerial self-interest on corporate capital structure. The Journal of Finance, 43(2), 271-281.

Gibson, C. H. (2001). Financial reporting and analysis: Using financial accounting information. South-Western Pub.

Graham, J. R. (2000). How big are the tax benefits of debt? The Journal of Finance, 55(5), 19011941.

Hamilton, R. T., \& Fox, M. A. (1998). The financing preferences of small firm owners. International Journal of Entrepreneurial Behavior \& Research, 4(3), 239-248. 
Holmes, S., \& Kent, P. (1991). An empirical analysis of the financial structure of small and large Australian manufacturing enterprises. Journal of Small Business Finance, 1(2), 141154.

Huang, R., \& Ritter, J. R. (2009). Testing theories of capital structure and estimating the speed of adjustment. Journal of Financial and Quantitative Analysis, 44(2), 237-271.

Impson, M. (1997). Market reaction to dividend-decrease announcements: public utilities vs. unregulated industrial firms. Journal of Financial Research, 20(3), 407-422.

Jahanzeb, A., Bajuri, N., \& Karami, M. (2013). Trade-off theory, pecking order theory, and market timing theory: a comprehensive review of capital structure theories. International Journal of Management and Commerce Innovations, 1(1), 11-18.

John, K., \& Williams, J. (1985). Dividends, dilution, and taxes: A signaling equilibrium. The Journal of Finance, 40(4), 1053-1070.

Kale, J. R., Noe, T. H., \& Ramirez, G. G. (1991). The effect of business risk on corporate capital structure: Theory and evidence. The Journal of Finance, 46(5), 1693-1715.

Kim, W. S., \& Sorensen, E. H. (1986). Evidence on the impact of the agency costs of debt on corporate debt policy. Journal of Financial and Quantitative Analysis, 21(2), 131-144.

Kotz, S., Johnson, H. L., \& Read, C. B. (1982). Encyclopedia of statistical sciences.

Kraft, J., Qu, Y., Quatraro, F., \& Ravix, J. L. (2013). Corporate governance, value, and performance of firms. University of Nice Sophia Antipolis.

Kraus, A., \& Litzenberger, R. H. (1973). A state-preference model of optimal financial leverage. The Journal of Finance, 28(4), 911-922.

Kristianti, R. A. (2013). Determinants of Firm Value and Debt Policy as Moderating Variable at Manufacturing Companies that Distribute Dividend, Accessed on December 12, 2013.

Lie, E. (2005). On the timing of CEO stock option awards. Management Science, 51(5), 802812.

Mardiastanto, F., \& Raharjo, K. (2014). Abrar.(2016). Pengaruh Insider Ownership, Profitabilitas, Kebijakan Hutang, Kebijakan Dividen Terhadap Nilai Perusahaan (Studi Kasus Pada Perusahaan Manufaktur Di BEI Tahun 2010-2013). Journal of Accounting, 2(2).

Miller, M. H., \& Rock, K. (1985). Dividend policy under as ymmetric information. The Journal of Finance, 40(4), 1031-1051.

Modigliani, F., \& Miller, M. (1958). The cost of capital, corporation finance, and the theory of finance. American Economic Review, 48(3), 291-297. 
Muhammad, H., Shah, B., \& ul Islam, Z. (2014). The impact of capital structure on firm performance: Evidence from Pakistan. 산경연구논집(IJIDB), 5(2), 13-20.

Mustofia, M., Puspitaningtyas, Z., \& Sisbintari, I. (2019). Pengaruh Profitabilitas dan Investment Opportunity Set terhadap Kebijakan Deviden. Jurnal Akuntansi Aktual, 2(4), 219-228.

Myers, S. C. (1977). Determinants of corporate borrowing. Journal of Financial Economics, $5(2), 147-175$.

Myers, S. C. (1984). The capital structure puzzle. The Journal of Finance, 39(3), 574-592.

Myers, S. C., \& Majluf, N. S. (1984). Corporate financing and investment decisions when firms have information that investors do not have. Journal of Financial Economics, 13(2), $187-221$.

Nieh, C.-C., Yau, H.-Y., \& Liu, W.-C. (2008). Investigation of target capital structure for electronic listed firms in Taiwan. Emerging Markets Finance and Trade, 44(4), 75-87.

Nissim, D., \& Ziv, A. (2001). Dividend changes and future profitability. The Journal of Finance, 56(6), 2111-2133.

Prasetia, T. E., Tommy, P., \& Saerang, I. (n.d.). S. 2014. Struktur Modal, Ukuran Perusahaan Dan Risiko Perusahaan Terhadap Nilai Perusahaan Otomoti Yang Terdaftar Di BEI, 2302-1174.

Reswari, A., Wahyudi, S., \& PENGESTUTI, I. D. (2016). ANALISIS PENGARUH RISIKO BISNIS, FIRM SIZE, PERTUMBUHAN PENJUALAN DAN INSTITUTIONAL OWNERSHIP TERHADAP STRUKTUR MODAL DAN DAMPAKNYA PADA NILAI PERUSAHAAN Studi Pada Perusahaan Manufaktur yang Listed di Bursa Efek Indonesia (Tahun 2012-2014). Diponegoro University.

Ria, Y., \& Lestari, P. V. (2015). Pengaruh Risiko Bisnis, Ukuran Perusahaan Dan Pertumbuhan Penjualan Terhadap Struktur Modal. E-Jurnal Manajemen, 4(5).

Rodoni, A., \& Ali, H. (2010). Manajemen keuangan. Jakarta: Mitra Wacana Media.

Salim, M., \& Yadav, R. (2012). Capital structure and firm performance: Evidence from Malaysian listed companies. Procedia-Social and Behavioral Sciences, 65, 156-166.

Scott Jr, J. H. (1976). A theory of optimal capital structure. The Bell Journal of Economics, 3354.

Shyam-Sunder, L., \& Myers, S. C. (1999). Testing static tradeoff against pecking order models of capital structure. Journal of Financial Economics, 51(2), 219-244.

Sia, V. L. R., \& Tjun, L. T. (2011). Pengaruh current ratio, earnings per share, dan price earnings ratio terhadap harga saham. Jurnal Akuntansi, 3(2), 136-158. 
Titman, S., \& Wessels, R. (1988). The determinants of capital structure choice. The Journal of Finance, 43(1), 1-19.

Van Horne, J. C., Wachowicz, J. R., \& John, M. (2013). Manajemen Keuangan. Edisi Ketiga Belas, Salemba Empat, Jakarta.

Wald, J. K. (1999). How firm characteristics affect capital structure: an international comparison. Journal of Financial Research, 22(2), 161-187.

Weston, J. F., \& Copeland, T. E. (2010). Manajemen Keuangan. Erlangga.

Wiagustini, N. L. P., \& Pertamawati, N. P. (2015). Pengaruh risiko bisnis dan ukuran perusahaan terhadap struktur modal dan nilai perusahaan pada perusahaan farmasi di bursa efek Indonesia. Matrik: Jurnal Manajemen, Strategi Bisnis Dan Kewirausahaan.

Woolridge, J. R. (1982). The information content of dividend changes. Journal of Financial Research, 5(3), 237-247.

Yeniatie, Y., \& Destriana, N. (2010). Faktor-faktor yang mempengaruhi kebijakan hutang pada perusahaan nonkeuangan yang terdaftar di Bursa Efek Indonesia. Jurnal Bisnis Dan Akuntansi, 12(1), 1-16. 